\title{
Core-shell polymer nanocomposite based on free radical copolymerization of anthranilic acid and o-amino phenol in the presence of copper hexacyanoferrates nanoparticles and its adsorption properties
}

\author{
A. M. Metwally ${ }^{1}$ M. M. Azab ${ }^{1}$ - A. A. Mahmoud ${ }^{1} \cdot$ H. M. Ali ${ }^{1}$ - A. F. Shaaban ${ }^{1}$
}

Received: 22 September 2021 / Accepted: 7 February 2022 / Published online: 26 February 2022

(c) The Author(s) 2022

\begin{abstract}
Core-shell polymer nanocomposite (CSNC) of copper hexacyanoferrate-copolymer of anthranilic acid with o-aminophenol (CHCF-poly(AA-co-OAP)) was synthesized and used as ion exchanger for the sorption of cesium ions from aqueous solution. The nanocomposite was prepared by implantation of CHCF nanoparticles into copolymer of poly(AA-co-OAP) during the polymerization process. The surface morphology and the porous structure were investigated through transmission electron microscope (TEM), scanning electron microscope (SEM) and Brunauer-Emmett-Teller (BET). The characterization of the prepared (CSNC) was carried out by Fourier transform infrared spectroscopy (FT-IR), X-ray diffraction (XRD) and Thermogravimetric (TGA). Which SEM and TEM images confirmed the nano-size of the prepared CSNC. The values of adsorption capacity of CSNC towards cesium ions and the factors influence on the removal of cesium from solutions were investigated as function in $\mathrm{pH}$, metal ion concentration, temperature and contact time. The results illustrated that the highest value of sorption capacity of the prepared CSNC towards $\mathrm{Cs}^{+}$ions was $2.1 \mathrm{mmol} \mathrm{g}-1$ at pH $11,10 \mathrm{mmol} \mathrm{L}^{-1} \mathrm{Cs}^{+}$and $25^{\circ} \mathrm{C}$. Four modeling include on Langmuir, Freundlich, Temkin and Dubinin-Radushkevich (D-R) isotherms models were studied. According to the obtained data, Langmuir model considered the most suitable model, which suggest that the uptake of $\mathrm{Cs}^{+}$was monolayer and homogeneous. Also, the adsorption kinetics data was fitted well to pseudo-second-order model. Thermodynamic parameters were calculated in the temperature from 25 to $60{ }^{\circ} \mathrm{C}$ and the data revealed that $\mathrm{Cs}^{+}$sorption was endothermic, spontaneous, and more favorable at higher temperature. Up to $92 \%$ desorption of $\mathrm{Cs}^{+}$was completed with $2 \mathrm{M} \mathrm{KCl}$.
\end{abstract}

Keywords Core-shell nanocomposite (CSNC) · Anthranilic acid $\cdot o$-aminophenol $\cdot$ Copper hexacyanoferrate $\cdot$ Sorption

\section{Introduction}

A. M. Metwally

aml.metwaly@fsc.bu.edu.eg

H. M. Ali

hager.moustafa@fsc.bu.edu.eg

M. M. Azab

drmorsy2000@yahoo.com

A. A. Mahmoud

amal.ahmed@fsc.bu.edu.eg

A. F. Shaaban

afshaaban@hotmail.com

1 Chemistry Department, Faculty of Science, Benha University, Benha, Egypt
Since twenty years in research area, the core-shell nanomaterials have great attention due to their uses in different applications like catalysts, industrial and "the study of how life and medicine work together" applications [1-14]. The core-shell nanocomposites may be with different sizes and shapes of core and shell thickness with different surface "the study of the shapes of things". They may be spherical, centric, weird, star-like, or tubular in shape. The properties of core-shell depended on the size and shape, which varies from material to another. In different fields like medical biotechnology, molecular bioimaging, drug delivery and cancer therapy, core-shell nanoparticles are used. The surface of the nanoparticles is changed through functional groups or 
molecules or coated with a thin layer of other materials (with different voters/parts), they show improved properties compared to the non-functionalized uncoated particles [15-18].

One of the fission (things produced along with something else) of most current nuclear power plants is cesium. The release of these radioactive isotopes like ${ }^{134} \mathrm{Cs}^{+}$and ${ }^{137} \mathrm{Cs}^{+}$ can show significant poison with the long-lived radionuclides (half-life $\sim 30$ years) accumulating in the environment [19]. The high solubility of cesium can cause its moving through underground water that supplies wells to the locations on the Earth that support life, which has possibly dangerous to human health and also to the environment. Also, cesium is chemically almost the same as potassium so it can be easily presented in terrestrial and aquatic organisms [20]. Cs metal can be adsorbed to the body and can be easily dispersed inside the soft tissues of body. The main problems of ${ }^{137} \mathrm{Cs}$ adsorption through the contaminated food and water is thyroid cancer [21].

Different technologies have been studied to remove cesium from aqueous solutions such as extraction, ion exchange, chemical precipitation, adsorption, and electrochemistry [22]. One of these methods is ion exchange process, which showed a lot of attracted views for removal of cesium from waste streams because of its convenience, efficiency and selectivity [23].

Excellent ion exchangers for cesium ions removal from aquatic solution are known as transition metals of hexacyanoferrates ( $\mathrm{Fe}, \mathrm{Cu}, \mathrm{Zn}, \mathrm{Ni}, \mathrm{Co}$ ) [24]. Copper hexacyanoferrate $(\mathrm{CuHCF})$ is among MHCFs, which characterized by the high value of adsorption capacity, chemical stability and selectivity over a range of $\mathrm{pH}$ [25]. The disadvantage of using the $\mathrm{CuHCF}$ to remove cesium radionuclides from the contaminated aquatic environment is unfeasibly separated from aquatic solution after the adsorption. To overcome this drawback, the CuHCF powders are usually planted on various supporting or binding materials to fabricate composite adsorbents. By implantation of inorganic into the organic materials during the preparation process, the composite ion exchangers are generally obtained [26]. The active components in ion exchangers nanocomposite is the inorganic materials and organic materials are simply inactive binders.

The CuHCF has been immobilized on the chelating resin [27], polyurethane foam [28], polyacrylonitrile (PAN) [29], polyethersulfone (PES) [30], polycarbonate tracketched member [31] and polyvinyl alcohol (PVA) [32] to obtain the composite adsorbents for cesium ions.

In our previous work, nanoparticles of copolymer of anthranilic acid with o-aminophenol poly(AA-co-OAP) was synthesized and used as chelating resin for the sorption of copper ions from aqueous solution [33]. In this work, we prepared core-shell nanocomposite (CSNC) of copper hexacyanoferrate-copolymer of anthranilic acid with o-aminophenol poly(AA-co-OAP) and used as nanocomposite ion exchanger for the separation of cesium ions. The CHCF nanoparticles implanted in poly(AA-coOAP) during the copolymerization process. The synthesized CSNC was characterized by Fourier transform infrared spectroscopy (FT-IR), X-ray powder diffraction (XRD) and Thermogravimetric (TGA). The study of the surface shapes was also investigated by transmission electron microscope (TEM), scanning electron microscope (SEM). As function in $\mathrm{pH}$ of cesium solution, cesium ion concentration, temperature and contact time, the removal of cesium from aqueous solutions was reported. Also, the regeneration of cesium was studied.

\section{Synthesis \& characterization techniques}

\section{Materials}

Anthranilic acid (AA), o-aminophenol (OAP) (RDH) and ammonium peroxydisulfate (APS) were obtained from Merck, India. Copper sulfate $\left(\mathrm{CuSO}_{4} \cdot 5 \mathrm{H}_{2} \mathrm{O}\right)$, potassium hexacyanoferrate $\left(\mathrm{K}_{4}\left[\mathrm{Fe}(\mathrm{CN})_{6}\right] 0.3 \mathrm{H}_{2} \mathrm{O}\right)$ and polyvinyl alcohol (PVA) were obtained from Sigma Aldrich Co., USA. Non-radioactive cesium chloride $(\mathrm{CsCl})$ was purchased from Alfa Aesar (China). Hydrochloric acid from Merck, India. All chemicals were used without further purification.

\section{Synthesis of the nanoparticles of copper hexacyanoferrate (CHCF)}

$\mathrm{CHCF}$ was prepared through the addition of $\mathrm{CuSO}_{4} \cdot 5 \mathrm{H}_{2} \mathrm{O}$ solution (10 wt \% was mixed in $50 \mathrm{ml}$ distilled water until completely dissolve) drop by drop to potassium hexacyanoferrate solution (10 wt \% was dispersed in $50 \mathrm{ml}$ of distilled water) with stirring. Then, PVA (6 wt \%) was dissolved in $100 \mathrm{ml}$ distilled water and added drop by drop to the above mentioned mixture of solutions. The reaction was left on magnetic stirrer for $24 \mathrm{~h}$ at room temperature. The reddish brown precipitate was filtered off next day, washed with distilled water for several times. Finally, the obtained reddish brown powder product was dried in air at room temperature and it was referred as $\mathrm{CHCF}$.

\section{Synthesis of core-shell nanocomposite (CSNC) of copper hexacyanoferrate-copolymer of anthranilic acid with o-aminophenol (poly(AA-co-OAP))}

CSNC was synthesized by plantation of nanoparticles of CHCF through free radical copolymerization of AA with OAP in the presence of APS as redox initiator. A mixture of anthranilic acid $(40 \mathrm{mmol})$ and o-aminophenol $(10 \mathrm{mmol})$ were dissolved in $20 \mathrm{ml}$ of $0.1 \mathrm{M} \mathrm{HCl}$ solution then nanoparticles of $\mathrm{CHCF}$ ( $3 \mathrm{wt} \%$ dispersed in $15 \mathrm{ml}$ of $0.1 \mathrm{M} \mathrm{HCl}$ ) 
was added drop by drop to the above solution with stirring. A fresh solution of APS (1.2 M) was added to the solution of anthranilic acid, o-amino phenol and CHCF nanoparticles. The reaction was left on magnetic stirrer for $24 \mathrm{~h}$. The black precipitate was filtered off next day, washed with $0.1 \mathrm{M}$ of $\mathrm{HCl}$ followed by deionized water several times, and dried in air at room temperature to give the black precipitate of CSNC.

\section{Characterization techniques}

Morphology and particle size of core-shell nanocomposite was determined using transmission electron microscopy (TEM) (JEOL [JEM-1230 electron microscopy]), the sample was obtained as follows: the fine powder was dispersed in water under ultra-sonication, and then one drop of the suspension was suspended and evaporated on a carbon coated copper grid and placed in the Phillips (CM/TEM). Also scanning electron microscope (SEM, FEI Inspect S, Oxford USA) with increasing speed beam (25-30) k.v with vacuum pressure $60 \mathrm{~Pa}$ and spot size (5-6) using back scattering detector for Z-imaging and an X-ray diffractometer was used to determine the morphology and particle size of core-shell nanocomposite. The IR spectra for the prepared $\mathrm{CHCF}$ nanoparticles and the core-shell nanocomposite were measured using Thermofisher Nicolete IS10, USA in the range of $400-4000 \mathrm{~cm}^{-1}$ Spectrophotometer. Thermal analysis experiments including Thermogravimetric (TGA) for the core-shell nanocomposite was carried out using SDT Q600 V20.9 Build 20, USA thermogravimetric analyzer. The experiment was performed in a dynamic atmosphere of nitrogen from room temperature to $1000{ }^{\circ} \mathrm{C}$ at heating rate of $10^{\circ} \mathrm{C} / \mathrm{min}$. Porous structure parameters of the core-shell nanocomposite was described by Brunauer-Emmett-Teller (BET) and BJH methods through $\mathrm{N}_{2}$ adsorption-desorption methods to inspect the porous properties of the nano-sized copolymers using nitrogen as the adsorbent at $77.35 \mathrm{~K}$. The measurements were executed using a model NOVA 3200 automated gas sorption system (Quantachrome, USA). The $\mathrm{X}$-ray diffraction of the prepared $\mathrm{CHCF}$ nanoparticles and the core-shell nanocomposite were obtained from Rigaku Oxford XtaLAB pro.

\section{Adsorption of cesium ions using CSNC by batch technique}

By batch technique, the adsorption properties of CSNC to $\mathrm{Cs}^{+}$ions were studied. The experiment was carried out as following, $0.1 \mathrm{~g}$ of the prepared core-shell nanocomposite was shaken with $100 \mathrm{ml}$ of cesium solution $(3 \mathrm{mmol} / \mathrm{L})$ at $25{ }^{\circ} \mathrm{C}$. At the end of time, the solution was filtered for phase separation and the concentration of supernatant solutions was measured by using Agilent Technologies 700 Series
ICP-OES. For the evaluations of adsorption capacity $\left(\mathrm{q}_{\mathrm{e}}\right)$ of the prepared core-shell nanocomposite, Eq. (1) was applied.

$q=\frac{\left(C_{0}-C_{e}\right) V}{W}$

where $\mathrm{C}_{\mathrm{o}}\left(\mathrm{mmol} \mathrm{L}^{-1}\right)$ and $\mathrm{C}_{\mathrm{e}}\left(\mathrm{mmol} \mathrm{L}^{-1}\right)$ are the initial and the equilibrium cesium concentrations, respectively; $\mathrm{V}(\mathrm{L})$ is the volume of the aqueous solution and $\mathrm{W}$ is the weight of dry CSNC in grams.

To study the influence of $\mathrm{pH}$ on the adsorption process of $\mathrm{Cs}^{+}$ions through CSNC, $100 \mathrm{ml}$ of $\mathrm{Cs}^{+}$solution $(3 \mathrm{mmol}$ $\mathrm{L}^{-1}$ ) was mixed with $0.1 \mathrm{~g}$ of $\mathrm{CSNC}$ at different $\mathrm{pH}$ values in the range from 3 to 11 . The $\mathrm{pH}$ of cesium solutions were adjusted by $0.1 \mathrm{M} \mathrm{HCl}$ and $0.1 \mathrm{M} \mathrm{NaOH}$. To study the effect of concentration on $\mathrm{Cs}^{+}$adsorption, adsorption experiments with different initial concentration of $\mathrm{Cs}^{+}$in the range of 2-10 $\mathrm{mmol} \mathrm{L}^{-1}$ were performed at optimum $\mathrm{pH}$. To investigate the effect of shaking time on adsorption of $\mathrm{Cs}^{+}$, the experiments were performed at different times $(0.5-3.5 \mathrm{~h})$ at optimum $\mathrm{pH}$ and optimum concentration of $\mathrm{Cs}^{+}$. The influence of temperature on the cesium uptake was performed at different temperatures 25,40 and $60{ }^{\circ} \mathrm{C}$, at optimum $\mathrm{pH}$ and $10 \mathrm{mmol} \mathrm{L}^{-1}$ of $\mathrm{Cs}^{+}$.

\section{Desorption}

The regeneration of the loaded CSNC by Cs was achieved using $2 \mathrm{M} \mathrm{KCl}$ at $25{ }^{\circ} \mathrm{C}$. To study the reusability of CSNC, five adsorption-desorption cycles were performed.

\section{Result and discussion}

\section{Synthesis of core-shell nanocomposite (CSNC) of CHCF- poly(AA-CO-OAP)}

A new CSNC was synthesized by the plantation of nanoparticles of $\mathrm{CHCF}$ during the free radical copolymerization of anthranilic acid with o-aminophenol. The synthesized CSNC used for sorption of cesium ions from aqueous solutions by ion-exchange process, which the potassium ions in CSNC replaced by cesium ions as shown in Scheme 1.

\section{Characterization of the synthesized CSNC}

\section{Morphology properties of CHCF and CSNC of CHCF-copolymer of anthranilic acid with o-aminophenol poly(AA-co-OAP)}

Figure 1 showed the surface properties of synthesized CHCF by SEM and TEM, which was confirmed the cuboid structure with the nanometer size of $25-50 \mathrm{~nm}$ of the prepared nanoparticles $\mathrm{CHCF}$. The core-shell structure of the 


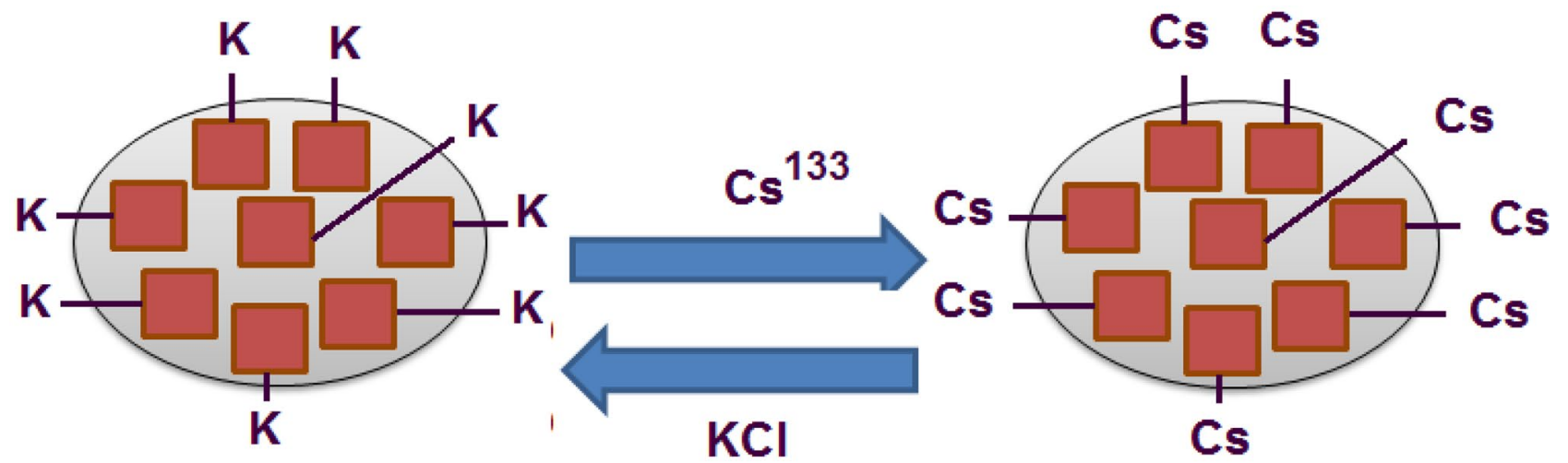

Poly(AA-Co-OAP)

Scheme 1 Ion-exchange process of potassium ions in CSNC by cesium ions in aqueous solutions

nanocomposite was confirmed by TEM techniques as shown in Fig. 2. The SEM-EDX and mapping spectra of CSNC samples before and after cesium adsorption were studied and shown in Figs. 3 and 4. The SEM images in Fig. 3a were studied to determine the distribution of the $\mathrm{CHCF}$ nanoparticles through poly(AA-co-OAP). These images indicated that the CHCF nanoparticles were uniformly distributed throughout the sample. Following cesium adsorption, it was shown that cesium was uniformly adsorbed with more bright which indicates that the cesium adsorption was emerged at after adsorption of cesium ions Fig. 4a, as compared with Fig. 3a.

To prove whether adsorption of cesium ions by CSNC, EDX elemental mapping spectra analysis were studied with SEM images. The cesium ion peaks were clearly appeared onto the surface of immobilized CSNC in Fig. 4b in compared with Fig. 3b. Also, the distribution of $\mathrm{K}^{+}$in composite before and after cesium adsorption was shown

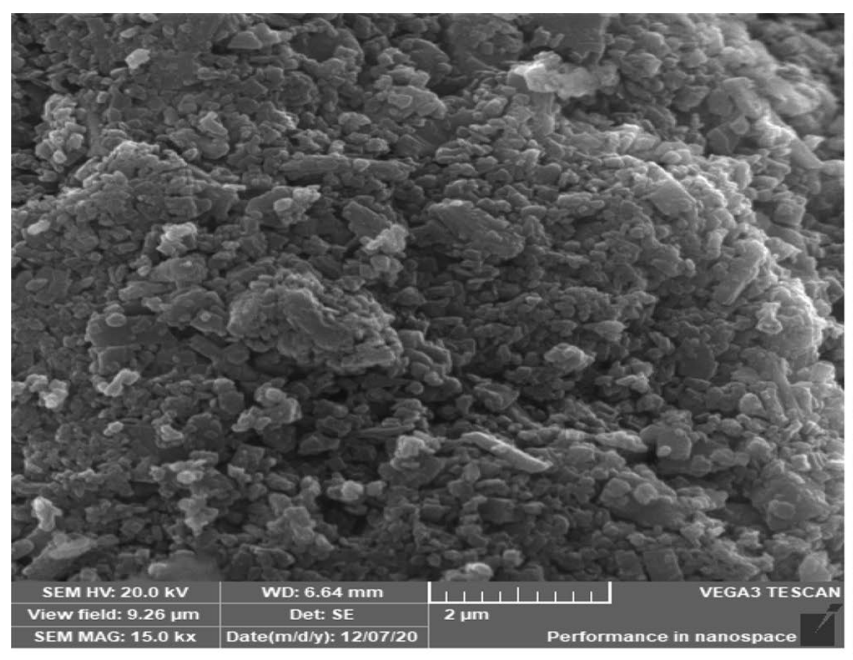

(a)

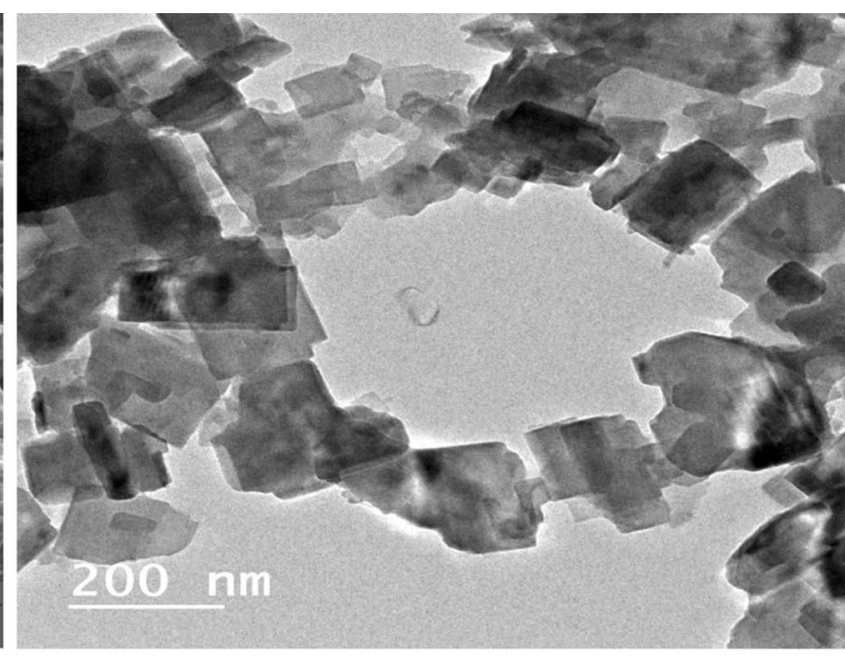

(b)

Fig. 1 (a) SEM and (b) TEM of the synthesized CHCF 


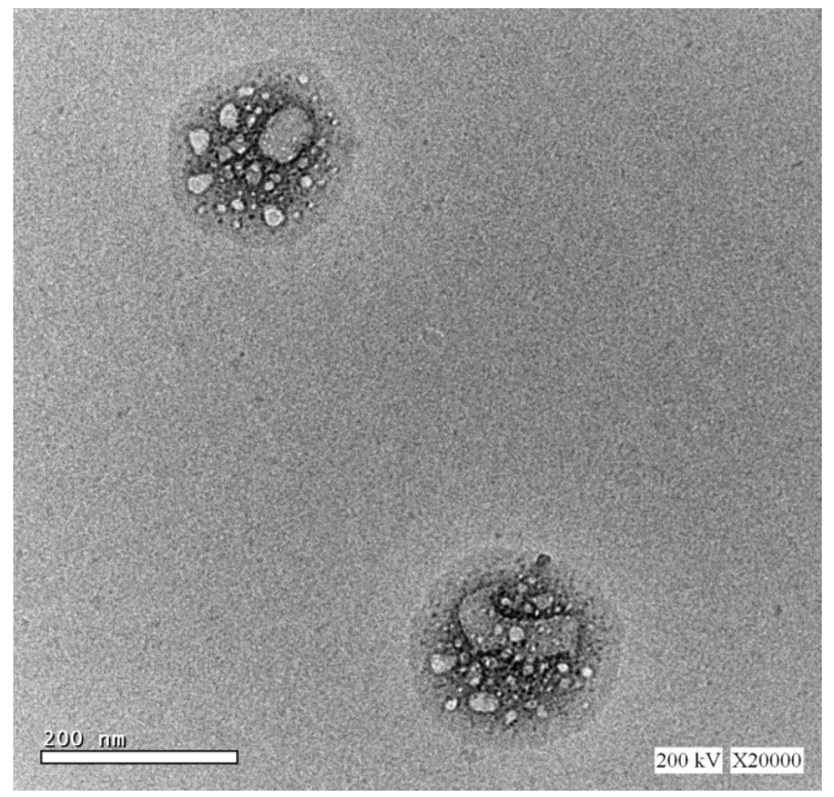

Fig. 2 TEM of the synthesized CSNC

in Figs. $3 b$ and $4 b$, which showed that the concentration of $\mathrm{K}^{+}$was decreased slightly after cesium adsorption. To observe the distribution of cesium and potassium ions before and after adsorption process (Figs. 3c and 4c), elemental mapping for CSNC samples before and after cesium adsorption was also studied. The images showed that homogeneous distribution of cesium ions with decreased in distribution of $\mathrm{K}^{+}$due to adsorption process occurs with good efficiency.

\section{FT- IR spectra of synthesized nanoparticles}

Figure 5 showed the spectra of the synthesized $\mathrm{CHCF}$ nanoparticles and CSNC. In Fig. 5a, the spectrum of CHCF exhibit sharp peak at $2095 \mathrm{~cm}^{-1}$ due to the stretching vibration of cyanide group $(\mathrm{C} \equiv \mathrm{N})$ and the bands in the $480-592 \mathrm{~cm}^{-1}$ region are due to the $(\mathrm{Fe}-\mathrm{C})$ stretching. Figure $5 \mathrm{~b}$ showed the spectrum of CSNC, which exhibit absorption peak at $3421 \mathrm{~cm}^{-1}$ attributed to $\mathrm{OH}$ group. The strong peak at $1684 \mathrm{~cm}^{-1}$ for the $\mathrm{C}=\mathrm{O}$ stretching. The peak in range $3315-3200 \mathrm{~cm}^{-1}$ is due to NH group. The spectrum showed peaks at $1630-1637 \mathrm{~cm}^{-1}$ and $1500-1571 \mathrm{~cm}^{-1}$ due to the $\mathrm{C}=\mathrm{C}$ of benzenoid and quinoid rings, respectively. Also, peaks at $1204-1244 \mathrm{~cm}^{-1}$ are attributed to the $\mathrm{C}-\mathrm{N}$ stretching of secondary aromatic amine. Also, Fig. 5b showed sharp peak at $2095 \mathrm{~cm}^{-1}$ due to the stretching vibration of cyanide group $(\mathrm{C} \equiv \mathrm{N})$ similar to that found in Fig. 5a for CHCF. This band indicated the plantation of $\mathrm{CHCF}$ nanoparticles in poly(AA-co-OAP).

\section{Surface area}

The BET surface area, BJH pore volume and average pore diameter for CSNC were determined by Brunauer- Emmett-Teller (BET) and BJH methods through $\mathrm{N}_{2}$ adsorption-desorption methods at $77.35 \mathrm{~K}$. The data illustrated that the CSNC has surface area $12.430 \mathrm{~m}^{2} / \mathrm{g}$, this leads to an efficient transfer of the metal ions to the internal adsorption sites [34].

\section{X-Ray diffraction (XRD)}

The X-ray diffraction (XRD) patterns of CHCF nanoparticles and CSNC were shown in Fig. 6. In Fig. 6a showed the diffraction patterns of $\mathrm{CHCF}$ nanoparticles, which showed a characteristic peaks at $2 \theta$ values of 17.5, 24.9, 35.9, 40.1, 44.2 , and $51.1^{\circ}$ which are due to Miller indexes of (200), (220), (400), (420), (424), and (440), respectively [35] of the cubic crystal structure of CHCF (with a cell constant of 9.99 A; JCPDS card no. 02-0383). Figure 6b showed the X-ray diffraction patterns of CSNC, which exhibited peaks at at $2 \theta=25^{\circ}$ was characteristic of the van der Waals distances between stacks of phenylene rings (polyanthranilic and poly o-aminophenol rings) [33] and additional peaks similar to diffraction peaks of CHCF (Fig. 6a). Thus, the XRD data confirms the presence of $\mathrm{CHCF}$ in the copolymer matrix.

\section{Thermogravimetric analysis}

The thermal stability of the prepared CSNC was evaluated and shown in Fig. 7. Four stages decomposition pattern were recorded. The first weight loss step started from range 27.89 to $159.18^{\circ} \mathrm{C}$ which corresponds to the loss of water molecules, free acids, and volatile molecules in the CSNC. The second step at temperature range $159.64-327.6{ }^{\circ} \mathrm{C}$ which represents loss of dopant bound to the copolymer chain and evolution of $\mathrm{CO}_{2}$. The third step was temperature range $328.6-502.73{ }^{\circ} \mathrm{C}$, which because of loss of sublimation and removal of low molecular weight polymer from the CSNC matrix [33]. The fourth step at temperature range 503.77-799.06 ${ }^{\circ} \mathrm{C}$ which is due to the complete degradation and decomposition of the polymer backbone. Above $799.06{ }^{\circ} \mathrm{C}$, the results obtained were associated with the residues only.

\section{Adsorption of cesium ions on core-shell nanocomposite (CSNC)}

Effect of $\mathrm{pH}$ The $\mathrm{pH}$ of the aquatic solutions is one of the important factors which affecting the adsorption performance of CSNC towards cesium ion. The sorption behavior of CSNC was studied at $\mathrm{pH}$ in range of 3-11 to optimum the best $\mathrm{pH}$, which recorded the maximum adsorption capacity of Cs on CSNC. Figure 8 showed the adsorption capacity 

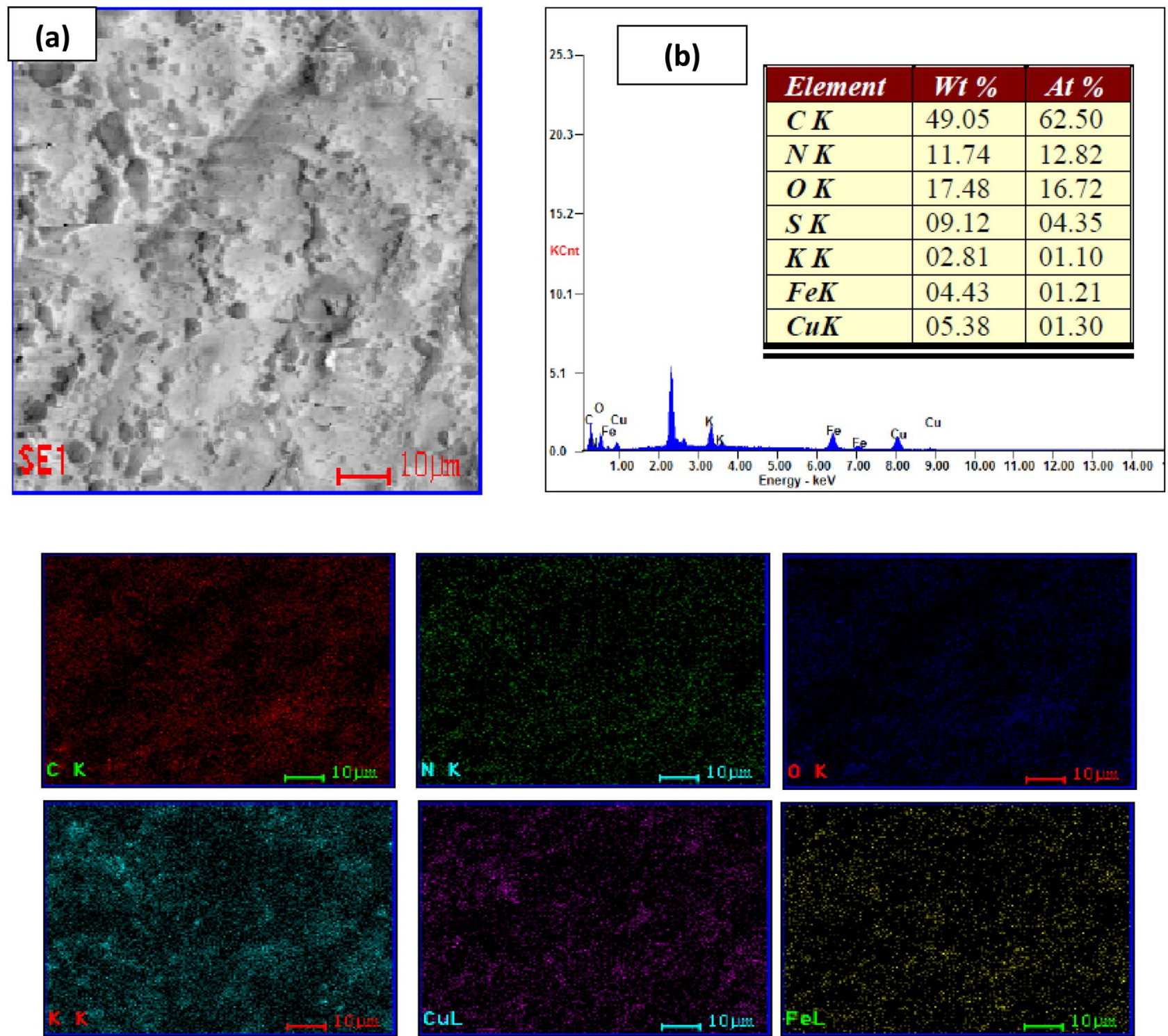

(c)

Fig. 3 SEM-EDX and mapping spectra of CSNC sample before cesium adsorption

of $\mathrm{Cs}$ at different pH. From Fig. 8, we concluded that the increasing in $\mathrm{pH}$ of aquatic solutions showed increasing in adsorption capacity of Cs ions onto CSNC. The maximum adsorption capacity was $1.26 \mathrm{mmol} \mathrm{g}^{-1}$ at $\mathrm{pH} 11$, thus all further experiments in the present study were performed at $\mathrm{pH} 11$. Also, we observed that the relative low adsorption at $\mathrm{pH} 3,4$ and 5 may be due to one of two reasons or both of them. The first reason is the competitive adsorption between $\mathrm{Cs}^{+}$and the $\mathrm{H}^{+}$ions from carboxyl groups [36]. The second reason is the dissolution of a fraction of $\mathrm{CuHCF} /$ poly(AA-co-OAP) surface under acidic conditions [37]. It is assumed that in acidic condition, $\mathrm{H}+$ ions occupy the active sites of the adsorbent. For this reason, Cs ions have to face a repulsive force with the higher concentrated $\mathrm{H}+$ ions during the adsorption process. However, when the surface of the adsorbents was deprotonated in alkali conditions then the electrostatic interaction between adsorbents surface and $\mathrm{Cs}$ ions increased. Therefore, the Cs adsorption enhanced at higher $\mathrm{pH}$ [35-39].

Effect of initial $\mathrm{Cs}+$ concentration and equilibrium isotherm models To study the effect of concentration of cesium on sorption process, experiments were carried out using different initial concentrations of $\mathrm{Cs}^{+}$from 2 to $10 \mathrm{mmol} \mathrm{L}^{-1}$ 

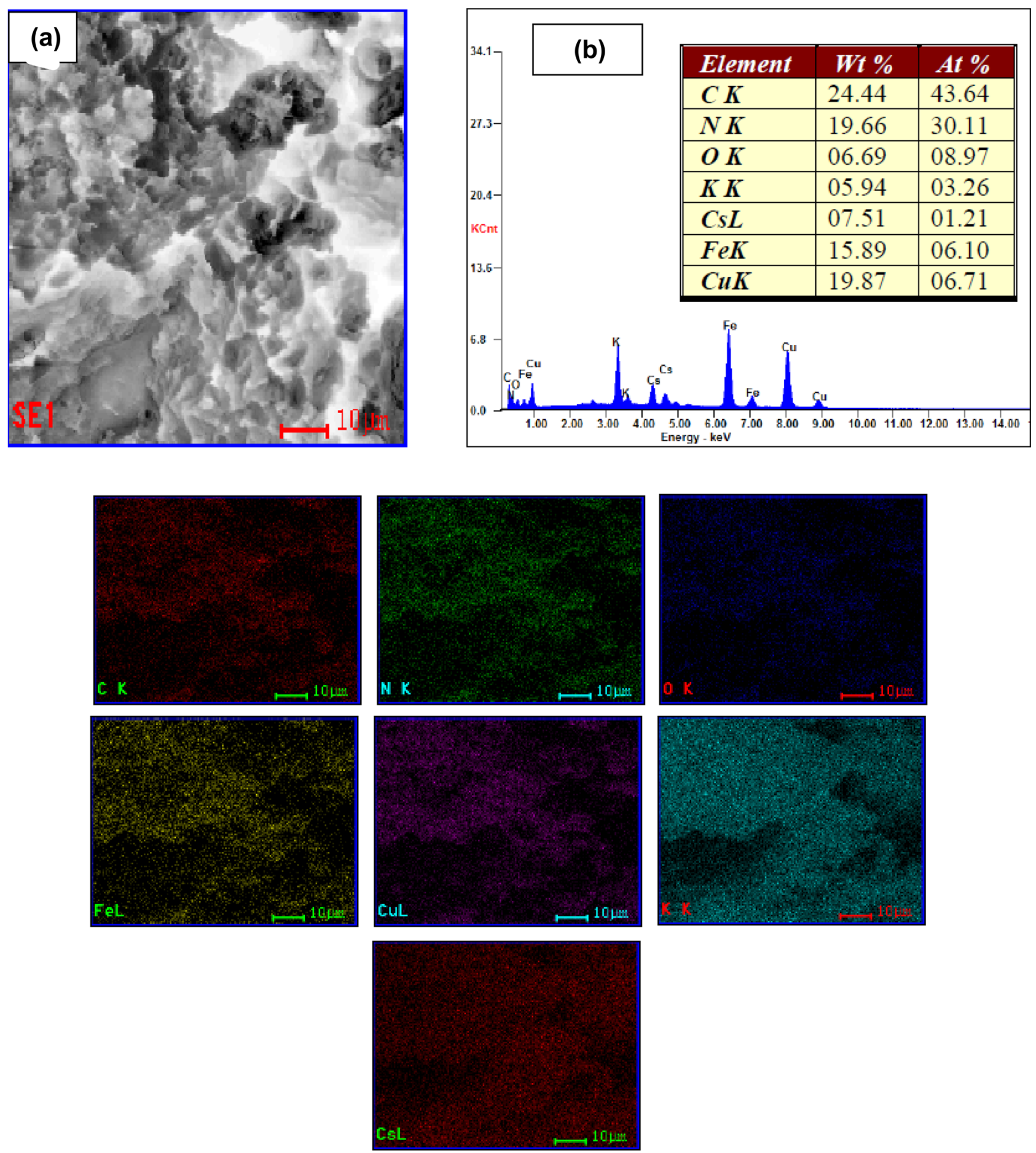

(c)

Fig. 4 SEM-EDX and mapping spectra of CSNC sample after cesium adsorption

at $25{ }^{\circ} \mathrm{C}$ and $\mathrm{pH}=11$. The obtained results showed that the uptake of $\mathrm{Cs}^{+}$increased with the increasing the initial concentration of $\mathrm{Cs}^{+}$to reach maximum capacity at initial concentration equal to $10 \mathrm{mmol} \mathrm{L}^{-1}$ of $2.1 \mathrm{mmol} \mathrm{g}^{-1}$ (Fig. 9).
Adsorption isotherm models To understand the mechanism of the adsorption process of cesium using CSNC four isotherm models were applied. The four isotherm models include Langmuir, Freundlich, Temkin and Dubinin-Radushkevich (D-R), 


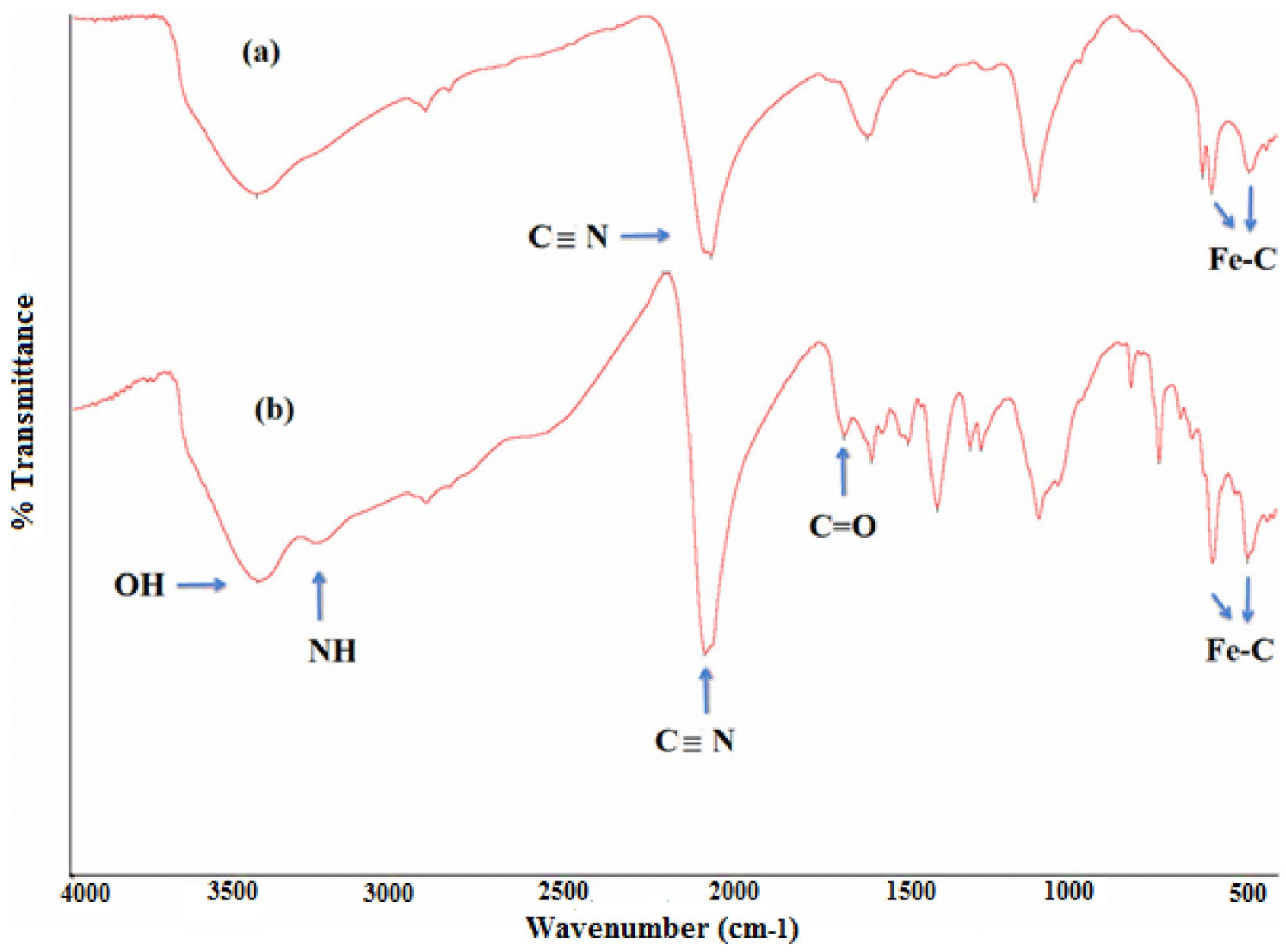

Fig. 5 FT-IR spectra for (a) CHCF nanoparticles and (b) CSNC

which were examined for studying the distribution of $\mathrm{Cs}^{+}$ between the aqueous solution and the prepared composite. After applying four isotherm models, the $\mathrm{Cs}^{+}$affinity, surface properties, sorption capacity, and sorption mechanism can be expalined. The Langmuir isotherm (Eq. 2) [40] was applied by plotting $\mathrm{C}_{\mathrm{e}} / \mathrm{q}$ versa. $\mathrm{C}_{\mathrm{e}}$ to give straight line, $\mathrm{Q}_{\max }$ and $\mathrm{K}$ are calculated from slope and intercept, respectively (Fig. 10).

$\frac{\mathrm{C}_{\mathrm{e}}}{\mathrm{q}}=\frac{\mathrm{C}_{\mathrm{e}}}{\mathrm{Q}_{\max }}+\frac{1}{\mathrm{KQ}_{\max }}$

where $\mathrm{C}_{\mathrm{e}}\left(\mathrm{mmolL}^{-1}\right)$ is the concentration of $\mathrm{Cs}^{+}$after equilibrium; $\mathrm{q}$ and $\mathrm{Q}_{\max }\left(\mathrm{mmolg}^{-1}\right)$ are amount of $\mathrm{Cs}^{+}$adsorbed at equilibrium and maximum adsorption, respectively. $\mathrm{K}$ $\left(\mathrm{Lmmol}^{-1}\right)$ is the Langmuir affinity constant.

The Freundlich isotherm (Eq. 3) [41] was applied by plotting $\log q$ versa. $\log C_{e}$ to give straight line, the freundlich constants are calculated from slope and intercept (Fig. 10). The Freundlich isotherm can be explained that the adsorption of cesium ions onto CSNC is heterogeneous. $\log \mathrm{q}=\mathrm{N} \log \mathrm{C}_{\mathrm{e}}+\log \mathrm{K}_{\mathrm{F}}$

where $\mathrm{K}_{\mathrm{F}}\left(\mathrm{mmolg}^{-1}\right)$ and $\mathrm{N}$ are the Freundlich constants related to the adsorption capacity and sorption intensity, respectively.

The third isotherm model is Temkin isotherm model which assumes that the heat of adsorption of cesium ions decreases linearly with coverage due to indirect adsorbate-adsorbate interactions. The Temkin isotherm (Eq. 4) [42] was applied by plotting $q$ versa. $\ln \mathrm{C}_{\mathrm{e}}$ to give straight line, the Temkin constants can be calculated from slope and intercept (Fig. 10).

$\mathrm{q}=\mathrm{B} \ln \mathrm{K}_{\mathrm{T}}+\mathrm{B} \ln \mathrm{C}_{\mathrm{e}}$

where $\mathrm{K}_{\mathrm{T}}\left(\mathrm{Lg}^{-1}\right)$ and $\mathrm{B}\left(\mathrm{Jmol}^{-1}\right)$ are constants related to equilibrium binding and heat of adsorption, respectively.

The fourth isotherm model is (D-R) model which applied to express the adsorption mechanism with a Gaussian energy distribution onto a heterogeneous surface. Dubinin-Radushkevich (D-R) (Eq. 5) [43] was applied by plotting $\ln q_{\mathrm{e}}$ versa. $\varepsilon^{2}$ to give straight line, the 


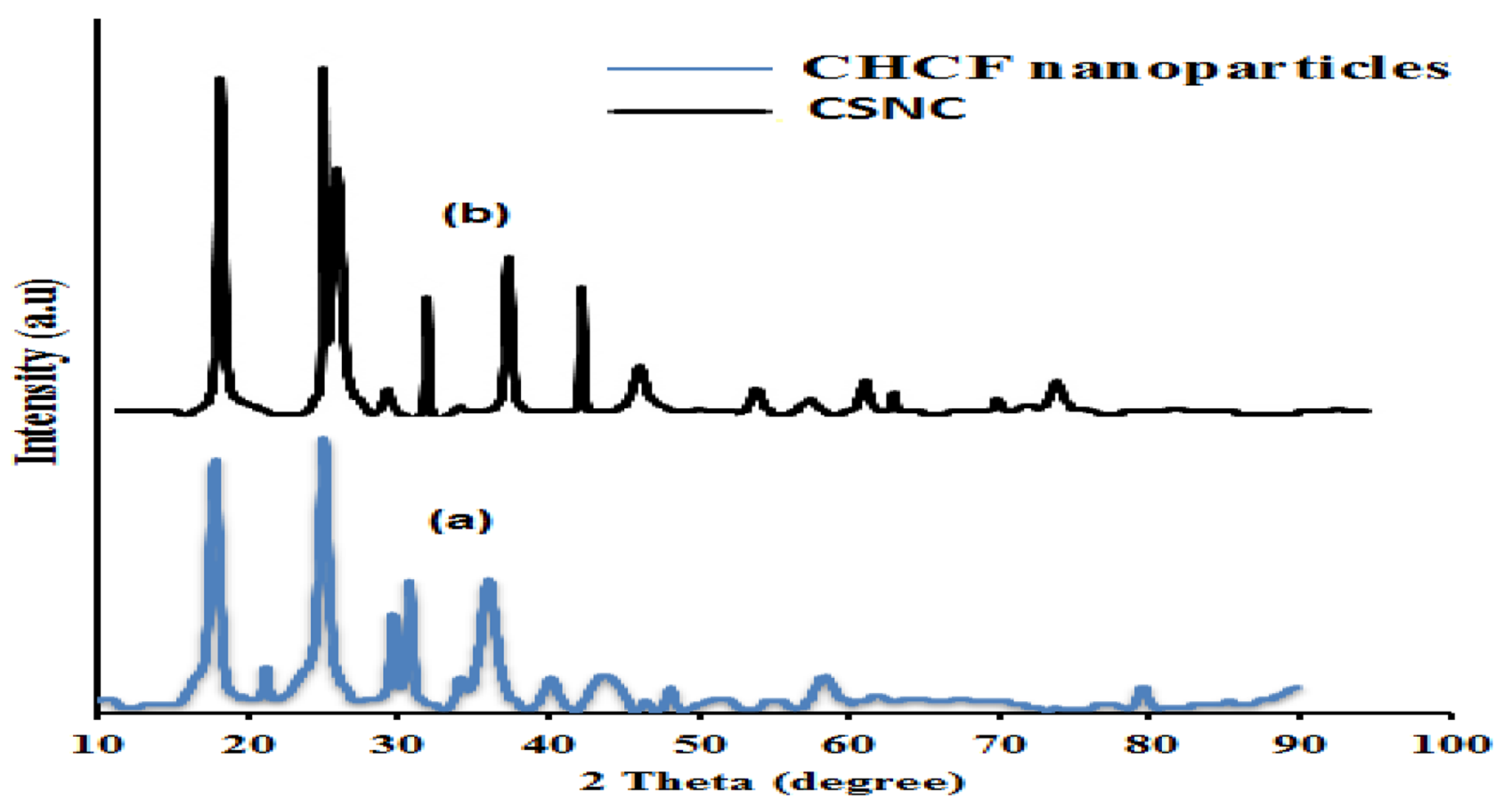

Fig. 6 X-ray diffraction (XRD) patterns of (a) CHCF nanoparticles and (b) CSNC

Temkin constants can be calculated from slope and intercept (Fig. 10).

$\operatorname{lnq} \mathrm{q}_{\mathrm{e}}=\ln \mathrm{Q}_{\max }-\mathrm{K}_{\mathrm{DR}} \varepsilon^{2}$

where $\mathrm{K}_{\mathrm{DR}}\left(\mathrm{mol}^{2} \mathrm{~kJ}^{-2}\right)$ is a constant which is related to mean free energy of adsorption, $\varepsilon\left(\mathrm{J} \mathrm{mol}^{-1}\right)$ represents the Polanyi potential which is related to the equilibrium concentration $\left(\mathrm{C}_{\mathrm{e}}\right)$ as indicated in the following equation:

$\varepsilon=\mathrm{RT} \ln \left(1+\frac{1}{\mathrm{C}_{\mathrm{e}}}\right)$

The mean sorption energy $\mathrm{E}(\mathrm{kJ} / \mathrm{mol})$, defined as the free energy change when one mole of ion is adsorbed to the surface of the solid from infinity in the solution, is calculated according to the following equation [44]:

$E=\frac{1}{\sqrt{2 \mathrm{~K}}}$

By studying the Langmuir sorption model, if the data fitted with this model, the sorption of cesium is homogeneous adsorption, which the solute molecules are adsorbed onto a homogenous and flat surface of adsorbent. Langmuir adsorption model can be explained in terms of dimensionless constant $\left(\mathrm{R}_{\mathrm{L}}\right)$, which is used to predict the affinity between the adsorbent and adsorbate. The $\mathrm{R}_{\mathrm{L}}$ value was given by the following equation:
$\mathrm{R}_{\mathrm{L}}=\frac{1}{1+\mathrm{KC}_{\mathrm{o}}}$

The $R_{L}$ values indicate the mechanism of the isotherm. Since the isotherm is unfavorable when $R_{L}>1$, linear when $\mathrm{R}_{\mathrm{L}}=1$, favorable when $0<\mathrm{R}_{\mathrm{L}}<1$ and irreversible when $R_{L}=0$ [45].

The four isotherm models were listed in Table 1. From Table 1, we concluded that the highest value of linear correlation coefficient, $\left(\mathrm{R}^{2}=0.9975\right)$ was obtained from Langmuir model which fitted with the collected results better than other three isotherm models. So we concluded that the sorption of $\mathrm{Cs}^{+}$occurs largely on homogenous surface by monolayer adsorption process. Since the obtained $\mathrm{R}_{\mathrm{L}}$ values lie between 0.14 and 0.45 (Table. 1), which proved that the equilibrium adsorption is favorable at higher initial concentration. As shown in Table 1, the lowest value of $R^{2}=0.9583$ for Dubinin-Radushkevich (D-R) isotherm indicated that this model not fitted with adsorption process in this work.

In Table 2, the commonly other adsorbents used to the adsorption of cesium (adsorption capacity) are listed and compared with the synthesized CSNC of this work. Also, the highest capacity was recorded for the synthesized CSNC of this work. These collected data reveals that the $\mathrm{CHCF} /$ poly(AA-co-OAP) nanocomposite is an effective adsorbent for the separation of cesium from aqueous solution and it can be used for treatment of large volumes 


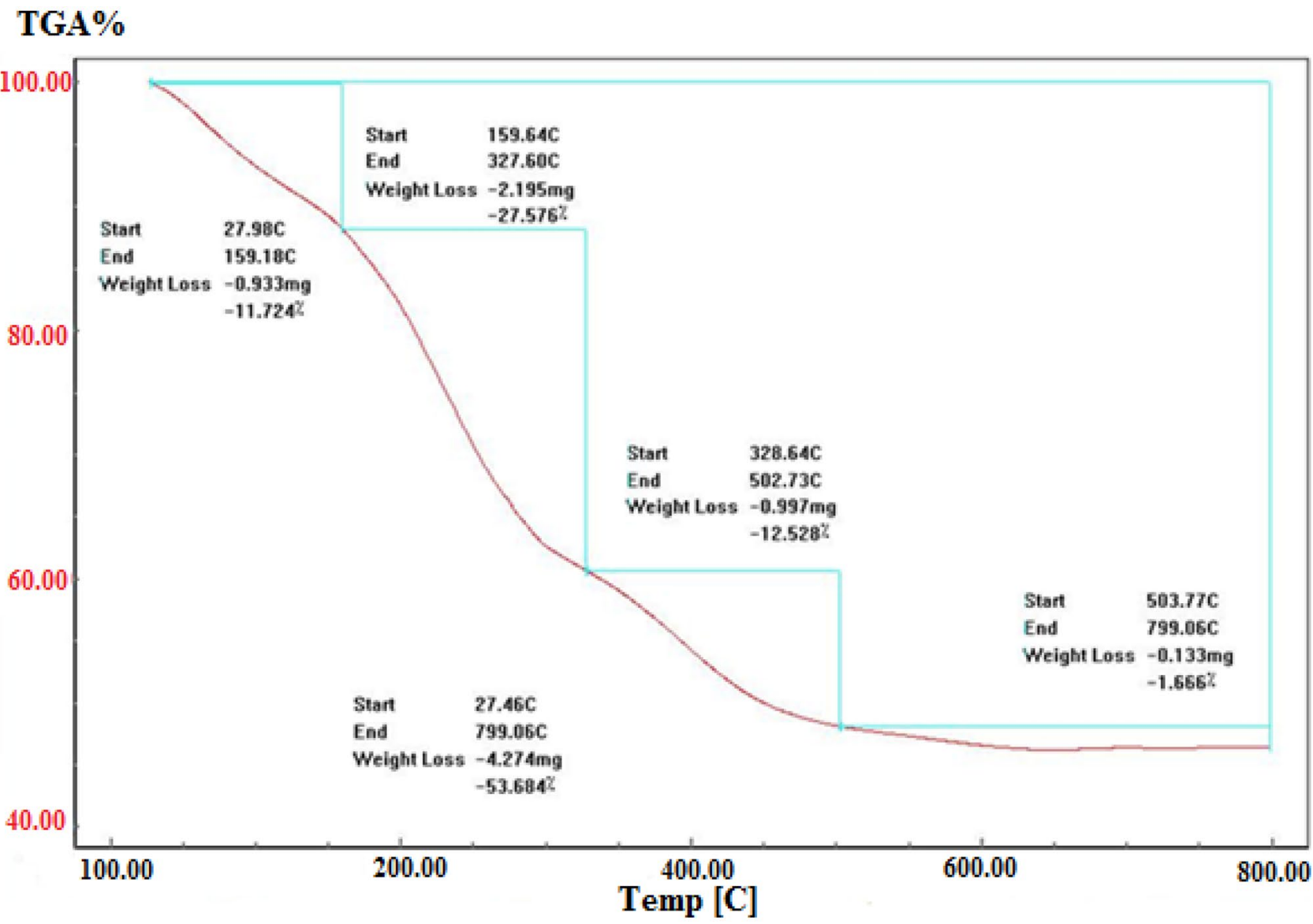

Fig. 7 TGA curve of the prepared CSNC

of radioactive contaminated water. Moreover, $\mathrm{CuHCF} /$ poly(AA-co-OAP) can be prepared by a simple and inexpensive materials.

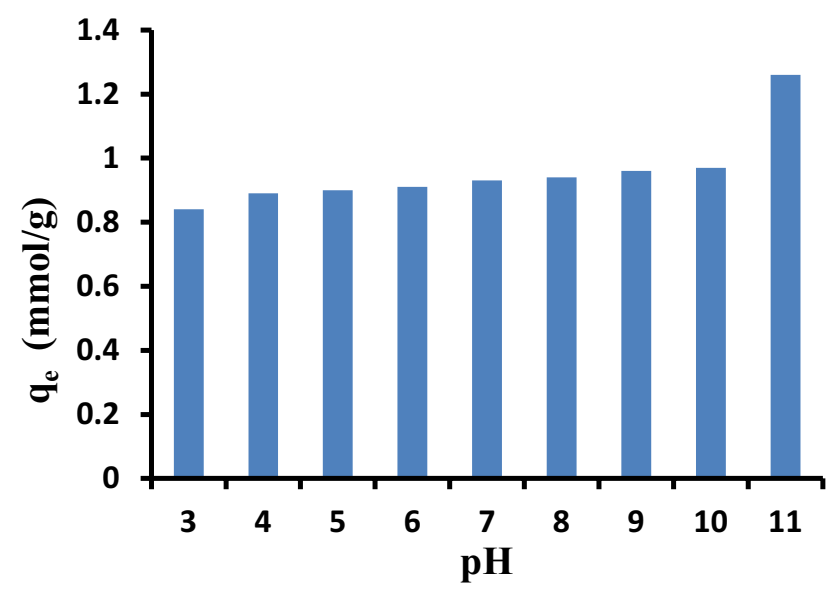

Fig. 8 Effect of $\mathrm{pH}$ on the uptake of $\mathrm{Cs}^{+}$ions; $100 \mathrm{ml}\left(3 \mathrm{mmol} \mathrm{L}^{-1}\right)$, $0.1 \mathrm{~g} \mathrm{CSNC}$, contact time $2 \mathrm{~h}$, shaking rate $250 \mathrm{rpm}$ and $25^{\circ} \mathrm{C}$
Effect of contact time and equilibrium kinetic models To examine the kinetics of adsorption process, a series of experiments was carried out to determine the optimal

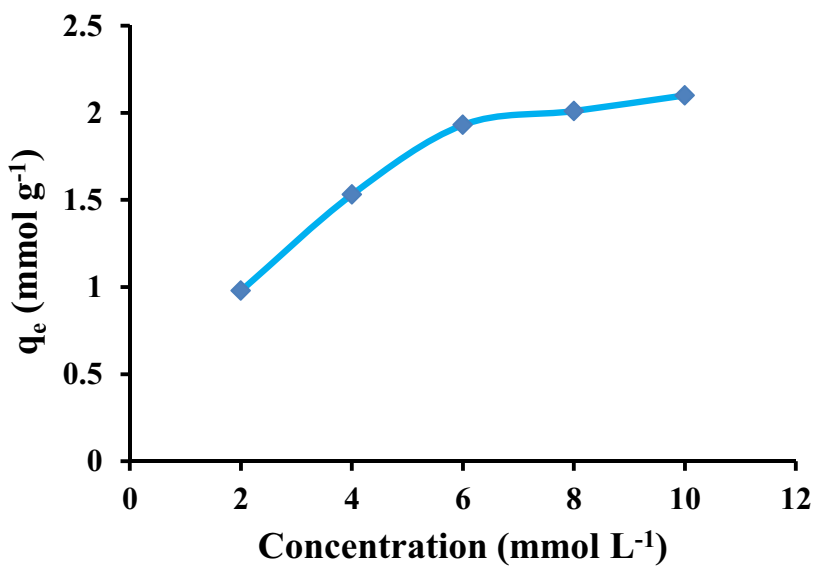

Fig. 9 Effect of initial Cs concentration on the sorption process; $100 \mathrm{ml}$ of $\mathrm{Cs}, 0.1 \mathrm{~g} \mathrm{CSNC}, \mathrm{pH} 11$, contact time $2 \mathrm{~h}$, shaking rate $250 \mathrm{rpm}$ and $25^{\circ} \mathrm{C}$ 
Fig. 10 Experimental adsorption isotherm (a), Langmuir adsorption isotherm (b)

Freundlich adsorption isotherm (c) Temkin adsorption isotherm and (d) Dubinin-Radushkevich (D-R) adsorption isotherm of cesium ions on the CSNC at room temperature and $\mathrm{pH} 11$
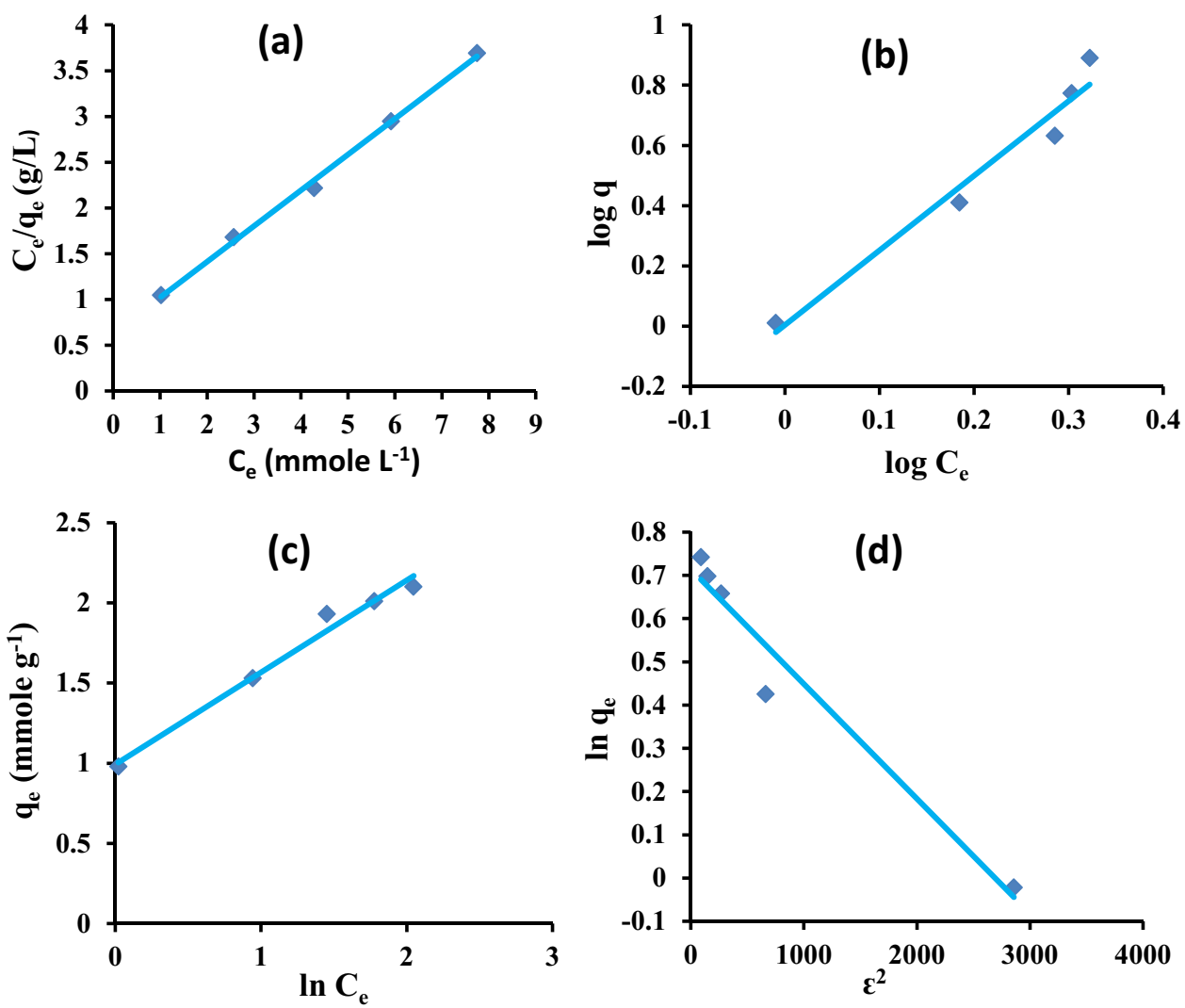

shaking time for uptake of $\mathrm{Cs}^{+}$onto CSNC in the shaking time range of 0.5-3.5 h. As shown in Fig. 11 it was observed that the adsorption of $\mathrm{Cs}^{+}$ions from aqueous solution using the nanocomposite adsorbent is continuously increased with time increase until reaching

Table 1 The parameters of Langmuir, Freundlich, Temkin and Dubinin Radushkevich (D-R) isotherms for the adsorption of cesium ions on the CSNC

\begin{tabular}{|c|c|c|}
\hline Isotherm & Parameters & Values \\
\hline \multirow[t]{5}{*}{ Langmuir } & $Q_{\max }($ Theortical $)\left(\mathrm{mmolg}^{-1}\right)$ & 2.56 \\
\hline & $\mathbf{Q}_{\max }\left(\right.$ Practical) $\left(\mathrm{mmolg}^{-1}\right)$ & 2.1 \\
\hline & $\mathrm{K}\left(\mathrm{Lmmol}^{-\mathbf{1}}\right)$ & 0.616 \\
\hline & $\mathbf{R}_{\mathbf{L}}$ & $0.14-0.45$ \\
\hline & $\mathbf{R}^{2}$ & 0.9975 \\
\hline \multirow[t]{3}{*}{ Freundlich } & $\mathbf{N}$ & 2.48 \\
\hline & $K_{f}\left(\mathbf{m m o l g}^{-1}\right)$ & 1.009 \\
\hline & $\mathbf{R}^{2}$ & 0.9631 \\
\hline \multirow[t]{3}{*}{ Temkin } & $\mathbf{K}_{\mathrm{T}}\left(\mathbf{L g}^{-1}\right)$ & 5.638 \\
\hline & B $\left(\mathrm{J} \mathrm{mol}^{-1}\right)$ & 0.574 \\
\hline & $\mathbf{R}^{2}$ & 0.9813 \\
\hline \multirow[t]{4}{*}{ D-R } & $Q_{\max }\left(\mathbf{m m o l g}^{-1}\right)$ & 2.04 \\
\hline & $\mathbf{K}_{\mathrm{DR}}\left(\mathbf{m o l}^{2} \mathbf{k J} \mathbf{J}^{-2}\right)$ & $3 \times 10^{-4}$ \\
\hline & $\mathbf{E}\left(\mathbf{k J ~ ~ m o l ^ { - 1 } )}\right.$ & 1291 \\
\hline & $\mathbf{R}^{2}$ & .9583 \\
\hline
\end{tabular}

equilibrium between two phases after $3 \mathrm{~h}$. Therefore, this obtained equilibrium time was selected for the next adsorption experiments. At the beginning of adsorption process, the rate of uptake was rapid, and the equilibration was achieved in $3 \mathrm{~h}$. This high initial adsorption rate towards $\mathrm{Cs}^{+}$indicates that the adsorption process occurs mainly on the nanocomposite surface and the regular distribution of $\mathrm{CHCF}$ inside poly(AA-co-OAP), making the rapid $\mathrm{Cs}^{+}$uptake at the beginning of the experiment. The fast removal process decreased the time needed for the adsorption of $\mathrm{Cs}^{+}$from wastewater which reduced the costs for the operation.

The kinetic process of adsorption of $\mathrm{Cs}^{+}$by CSNC can be investigated by using four kinetic models, including the pseudo-first-order (Eq. 9) [51], pseudo second order (Eq. 10) [52], intra-particle diffusion model (Eq. 12) [53], and Elovich equation (Eq. 13) [54] (Fig. 12).

$\log \left(q-q_{t}\right)=\log q-\left(\frac{K_{a d s}}{2.303}\right) t$

$\frac{\mathrm{t}}{\mathrm{q}_{\mathrm{t}}}=\frac{1}{\mathrm{~K}_{2} \mathrm{q}^{2}}+\left(\frac{1}{\mathrm{q}}\right) \mathrm{t}$

$\mathrm{h}=\mathrm{K}_{2} \mathrm{q}^{2}$ 
Table 2 Cesium adsorption capacities from other composites listed in recently published articles related to of metal hexacyanoferrates

\begin{tabular}{|c|c|c|c|c|}
\hline Support & Co-metal & $\begin{array}{l}\text { Sorption capacity } \\
\left(\mathrm{mmol} \mathrm{g}^{-1}\right)\end{array}$ & Conditions & Ref. \\
\hline CSNC & Cs & 2.1 & pH 11, $25^{\circ} \mathrm{C}$ & This study \\
\hline (CuHCF) graphene oxide granules (CGAGs) & Cs & 0.38 & $\mathrm{pH} 5,25^{\circ} \mathrm{C}$ & [46] \\
\hline copper hexacyanoferrate-PAN composite & Cs & 0.08 & pH 9, $25^{\circ} \mathrm{C}$ & [35] \\
\hline microporous composite (CuHCF/PP600) & Cs & 0.22 & pH $7,25^{\circ} \mathrm{C}$ & [47] \\
\hline (HCF-Mbead) & Cs & 0.52 & $\mathrm{pH} 12,25^{\circ} \mathrm{C}$ & {$[48]$} \\
\hline potassium copper hexacyanoferrate-cellulose hydrogel & Cs & 2.06 & pH $11,25^{\circ} \mathrm{C}$ & [49] \\
\hline nanofibers embedded with potassium copper hexacyanoferrate & Cs & 0.85 & $\mathrm{pH} 8,25^{\circ} \mathrm{C}$ & {$[50]$} \\
\hline
\end{tabular}

$\mathrm{q}_{\mathrm{t}}=\mathrm{K}_{\mathrm{id}} \mathrm{t}^{0.5}$

$\mathrm{q}_{\mathrm{t}}=\frac{1}{\beta} \ln (\alpha \beta)+\frac{1}{\beta} \ln \mathrm{t}$

where $\mathrm{q}$ and $\mathrm{q}_{\mathrm{t}}$ are capacities of $\mathrm{Cs}^{+}$adsorbed per unit mass of CSNC (mmolg $\left.{ }^{-1}\right)$ at equilibrium and at any time $\mathrm{t}(\mathrm{min})$, respectively; $\mathrm{K}_{\mathrm{ads}}\left(\mathrm{min}^{-1}\right), \mathrm{K}_{2}\left(\mathrm{~g} \mathrm{mmol}^{-1} \mathrm{~min}^{-1}\right)$ and $\mathrm{K}_{\mathrm{id}}$ $\left(\mathrm{mmolg}^{-1} \mathrm{~min}^{-0.5}\right)$ are the rate constants of the first-order, second order and intraparticle diffusion models, respectively; $\mathrm{h}\left(\mathrm{mmol} \mathrm{g}^{-1} \mathrm{~min}^{-1}\right)$ is the initial sorption rate constant. $\alpha\left(\mathrm{mmol} \mathrm{g}^{-1} \mathrm{~min}^{-1}\right)$ is the initial adsorption rate and $\beta\left(\mathrm{g} \mathrm{mmol}^{-1}\right)$ is the constant of the degree of the surface coverage and activation energy for chemisorptions.

Pseudo-first-order (Eq. 9), Pseudo second order (Eq. 10), Intra-particle diffusion model (Eq. 12), and Elovich equation (Eq. 13) are four models, which applied in this work in order to evaluate the mechanism of the kinetics of $\mathrm{Cs}^{+}$onto the CSNC. The kinetic parameters and correlation factor $\left(\mathrm{R}^{2}\right)$ were estimated and are listed in Table 3. The results reveal that the pseudo-second-order model $\left(\mathrm{R}^{2}=0.9587\right)$ is more suitable than other models. The fitness of pseudo-second-order kinetic model may mean that $\mathrm{Cs}^{+}$adsorbed on CSNC involving chemical

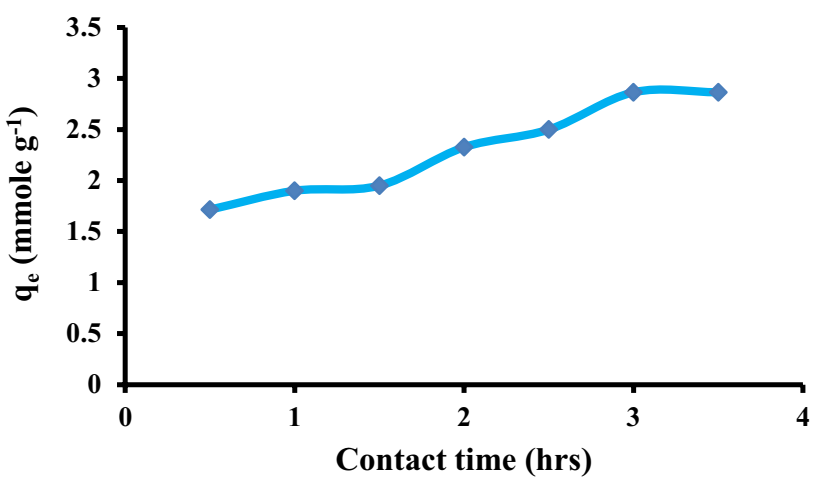

Fig. 11 Effect of contact time on the sorption process; $100 \mathrm{ml}$ of $\mathrm{Cs}$, $0.1 \mathrm{~g} \mathrm{CSNC}, \mathrm{pH} 11,10 \mathrm{~mol} \mathrm{~L}-1$, shaking rate $250 \mathrm{rpm}$ and $25^{\circ} \mathrm{C}$ reaction, which including ion exchange, substitution, or complexation $[22,55]$.

Influence of temperature and thermodynamic parameters The temperature plays an important role in the adsorption efficiency of $\mathrm{Cs}^{+}$on the CSNC so, the uptake of $\mathrm{Cs}^{+}$was studied with a temperature range of $25-60{ }^{\circ} \mathrm{C}$. The data in Fig. 13 showed the adsorption efficiency increased as the temperature was raised, indicating the endothermic nature of the process. Increasing the temperature is beneficial to bind of $\mathrm{Cs}^{+}$ to adsorption sites. To better evaluate the adsorption process, three thermodynamic parameters were carried out including Gibbs free energy $(\Delta \mathrm{G})$, enthalpy change $(\Delta \mathrm{H})$ and entropy change $(\Delta S)$.

The change of the standard Gibbs free energy $\Delta \mathrm{G}^{\circ}$ ads $\left(\mathrm{kJ} \mathrm{mol}^{-1}\right)$, the change of the standard enthalpy $\Delta \mathrm{H}_{\text {ads }}^{\circ}(\mathrm{kJ}$ $\left.\mathrm{mol}^{-1}\right)$, the change of the standard entropy $\Delta \mathrm{S}_{\text {ads }}^{\circ}\left(\mathrm{J} \mathrm{mol}^{-1}\right)$ are thermodynamic parameters, which can be obtained using Eqs. (14) and (15):

$\ln \mathrm{K}_{\mathrm{d}}=\frac{\Delta \mathrm{S}_{\mathrm{ads}}^{\circ}}{\mathrm{R}}-\frac{\Delta \mathrm{H}_{\mathrm{ads}}^{\circ}}{\mathrm{RT}}$

$\Delta \mathrm{G}^{\circ}{ }_{\mathrm{ads}}=-\mathrm{RT} \ln \mathrm{K}_{\mathrm{d}}$

where $\mathrm{T}$ is the absolute temperature $(\mathrm{K}), \mathrm{R}$ is the universal gas constant $\left(8.314 \mathrm{Jmol}^{-1} \mathrm{~K}^{-1}\right.$ ) and $\mathrm{K}_{\mathrm{d}}$ is the equilibrium distribution constant $\left(\mathrm{ml} \mathrm{g}^{-1}\right) . \mathrm{K}_{\mathrm{d}}$ was given by Eq. (16).

$\mathrm{K}_{\mathrm{d}}=\frac{\mathrm{C}_{\circ}-\mathrm{C}_{\mathrm{e}}}{\mathrm{C}_{\mathrm{e}}} \times \frac{\mathrm{V}}{\mathrm{W}}$

where $\mathrm{C}_{\mathrm{o}}\left(\mathrm{mmolL}^{-1}\right)$ is the initial $\mathrm{Cs}^{+}$concentration, $\mathrm{C}_{\mathrm{e}}$ $\left(\mathrm{mmolL}^{-1}\right)$ is the equilibrium $\mathrm{Cs}^{+}$concentration $\left(\mathrm{mmolL}^{-1}\right)$, $\mathrm{V}$ is the total volume of the solution in $(\mathrm{L})$ and $\mathrm{W}$ is the weight of the dry composite in gram.

The thermodynamic parameters are collected in Table 4. The calculated value of $\Delta \mathrm{H}$ is $0.708 \mathrm{~kJ} / \mathrm{mol}>0$ indicated that the adsorption process of $\mathrm{Cs}^{+}$on $\mathrm{CSNC}$ is endothermic reaction process. That is, increasing the temperature of the 
Fig. 12 (a) Pseudo-first-order, (b) Pseudo second order, (c) Intra-particle diffusion model and Elovich model
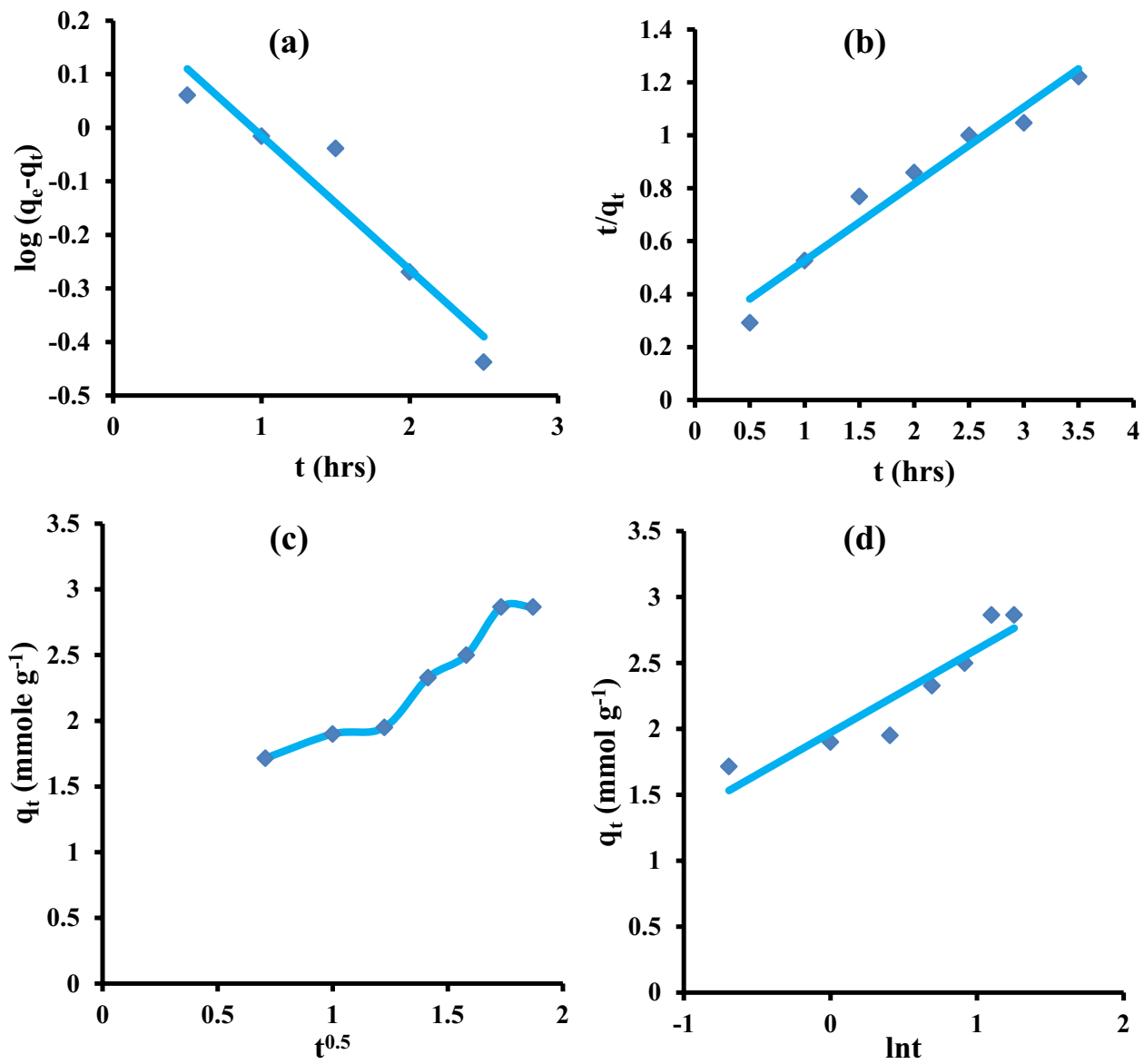

system can promote the adsorption of $\mathrm{Cs}^{+}$. Also, the values of $\left(\Delta \mathrm{G}_{\text {ads }}^{\circ}\right)$ were negative, which indicates the spontaneity and feasibility of $\mathrm{Cs}^{+}$adsorption. The positive value of standard entropy $\left(\Delta S^{\circ}\right.$ ads $)$ indicates the affinity of the prepared nanocomposite for $\mathrm{Cs}^{+}$and the increasing randomness at the (nanocomposite $/ \mathrm{Cs}^{+}$solution) interface during the

Table 3 The parameters of Pseudo-first-order, Pseudo second order, Intra-particle diffusion model and Elovich models for the cesium ions adsorption on the CSNC

\begin{tabular}{|c|c|c|}
\hline Equations & Parameters & Values \\
\hline \multirow{3}{*}{$\begin{array}{l}\text { Pseudo First order kinetic } \\
\text { equation }\end{array}$} & $q\left(\mathrm{mmolg}^{-1}\right)$ & 1.718 \\
\hline & $\mathbf{K}_{\mathrm{ads}}\left(\min ^{-1}\right)$ & 0.009 \\
\hline & $\mathbf{R}^{2}$ & 0.9124 \\
\hline \multirow[t]{4}{*}{ Pseudo Second-order kinetics } & $q\left(\mathrm{mmolg}^{-1}\right)$ & 3.45 \\
\hline & $\mathrm{K}_{2}\left(\mathrm{~g} \mathrm{mmol}^{-1} \mathrm{~min}^{-1}\right)$ & 0.0059 \\
\hline & $h\left(\mathbf{m m o l ~ g} \mathbf{g}^{-1} \min ^{-1}\right)$ & 0.0702 \\
\hline & $\mathbf{R}^{2}$ & 0.9587 \\
\hline \multirow[t]{3}{*}{ Elovich equation } & $\alpha\left(\mathrm{mmol}_{\mathrm{g}} \mathrm{g}^{-1} \cdot \mathrm{min}^{-1}\right)$ & 0.237 \\
\hline & $\beta\left(\right.$ g. $\left.\mathrm{mmol}^{-1}\right)$ & 1.579 \\
\hline & $\mathbf{R}^{2}$ & 0.8661 \\
\hline \multirow[t]{2}{*}{ Intraparticle diffusion equation } & $K_{\text {id }}\left(\operatorname{mmolg}^{-1} \min ^{-1 / 2}\right)$ & 0.027 \\
\hline & $\mathbf{R}^{2}$ & 0.6708 \\
\hline
\end{tabular}

uptake process. It can be observed that the removal efficiency was not significantly influenced due to the change of temperature. The marginal drop in Cs removal performance with increasing temperature may be resulted in the thermal destabilization which increased the mobility of Cs ions and inaugurated the desorption steps $[35,39,56]$.

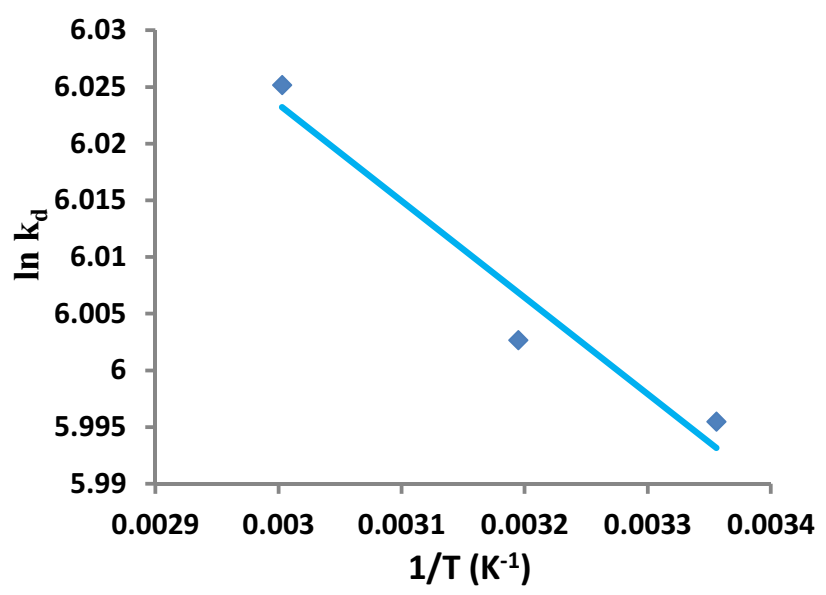

Fig. 13 The effect of temperature on the distribution coefficient of cesium ions on CSNC ion exchanger 
Table 4 Thermodynamic parameters for cesium adsorption on the synthesized CSNC ion exchanger

\begin{tabular}{ll}
\hline$\Delta \mathbf{H}^{\circ}(\mathrm{kJ} / \mathrm{mol})$ & +0.708 \\
\hline$\Delta \mathbf{S}^{\circ}(\mathrm{kJ} / \mathrm{K} \mathrm{mol})$ & +0.052 \\
Temp. $(\mathrm{K})$ & $-\Delta \mathrm{G}^{\circ}(\mathrm{kJ} / \mathrm{mol})$ \\
298 & 14.9 \\
313 & 15.6 \\
333 & 16.9 \\
\hline
\end{tabular}

\section{Desorption}

From the uptake-elution process, the regeneration efficiency can be calculated from the following Eq. (17):

Regeneration efficiency $=\frac{\text { Uptake of metal ion in the second cyle }}{\text { Uptake of metal ion in the first cycle }} \times 100$

From the uptake-elution, we observed that the adsorption capacity of newly synthesized CSNC was hardly affected even after five regeneration cycles. The results showed that adsorption capacity decreased from 100 to $98 \%, 97 \%, 95 \%$, 93\% and $92 \%$

\section{Conclusion}

For the first time, a low cost and facile route has been developed for the synthesis of core shell nanocomposite derived from $\mathrm{CHCF}$ and poly(AA-co-OAP). The synthesis route included (i) synthesis of nanoparticles of CHCF (ii) plantation the nanoparticles in polymer matrix of poly(AAco-OAP) during the copolymerization process. The structure of the prepared CSNC via FT-IR, X-ray powder diffraction (XRD) and Thermogravimetric (TGA), TEM and SEM-EDX mapping. The SEM and TEM confirmed the nano structure of the prepared CHCF and CSNC. Also, XRD analysis confirmed the expansion of the CHCF into poly(AA-co-OAP) and The synthesized CSNC used for sorption of cesium ions from aqueous solutions by ionexchange process between the potassium ions in CSNC replaced by cesium ions. FTIR analysis confirmed the presence of $\mathrm{CN}$ bonds in the CSNC adsorbents implying the successful plantation of $\mathrm{CHCF}$ on the copolymer, which was further supported by EDX mapping.

The sorption process of the synthesized CSNC towards cesium ions and the factors affecting on the cesium sorption from aqueous solutions were reported at the difference in $\mathrm{pH}$, metal ion concentration, shaking time and temperature. The results showed that the maximum capacity of the CSNC towards $\mathrm{Cs}^{+}$ions was $2.1 \mathrm{mmol} \mathrm{g}^{-1}$ at $\mathrm{pH} 11,10 \mathrm{mmol}$ $\mathrm{L}^{-1} \mathrm{Cs}^{+}$and $25^{\circ} \mathrm{C}$. Four modeling include on Langmuir,
Freundlich, Temkin and Dubinin-Radushkevich (D-R) isotherms models were studied, which the data were well fitted with Langmuir model suggesting that the uptake of $\mathrm{Cs}^{+}$was monolayer and homogeneous. Also, the adsorption kinetics results were fitted well to pseudo-second-order model. Thermodynamic parameters were calculated in the temperature range of $25-60{ }^{\circ} \mathrm{C}$ and the data revealed that $\mathrm{Cs}^{+}$sorption was endothermic, spontaneous, and more favorable at higher temperature. Up to $92 \%$ desorption of $\mathrm{Cs}^{+}$was completed with $2 \mathrm{M} \mathrm{KCl}$.

Funding Open access funding provided by The Science, Technology \& Innovation Funding Authority (STDF) in cooperation with The Egyptian Knowledge Bank (EKB).

\section{Declarations}

Conflict of interest All authors declare that they have no conflict of interest.

Open Access This article is licensed under a Creative Commons Attribution 4.0 International License, which permits use, sharing, adaptation, distribution and reproduction in any medium or format, as long as you give appropriate credit to the original author(s) and the source, provide a link to the Creative Commons licence, and indicate if changes were made. The images or other third party material in this article are included in the article's Creative Commons licence, unless indicated otherwise in a credit line to the material. If material is not included in the article's Creative Commons licence and your intended use is not permitted by statutory regulation or exceeds the permitted use, you will need to obtain permission directly from the copyright holder. To view a copy of this licence, visit http://creativecommons.org/licenses/by/4.0/.

\section{References}

1. Burda C, Chen X, Narayanan R, El-Sayed MA (2005) Chemistry and properties of nanocrystals of different shapes. Chem Rev 105:1025-1102

2. Zhang J, Ma N, Tang F, Cui Q, He F, Li L (2012) pH- and glucoseresponsive core-shell hybrid nanoparticles with controllable metal-enhanced fluorescence effects. ACS Appl Mater Interfaces 4:1747-1751

3. Al-Hussaini AS, Eltabie KR, Hassan MER (2018) Fabrication of core-shell nanocomposites with enhanced photocatalytic efficacy. Polym Int 67:1419-1428

4. Shwetharani R, Nayak V, Jyothi MS, Balakrishna RG (2020) Review on recent advances of core-shell structured lead halide perovskites quantum dots. J Alloys Compd 834:155246

5. Kumar KS, Kumar VB, Paik P (2013) Recent advancement in functional core-shell nanoparticles of polymers: Synthesis, physical properties, and applications in medical biotechnology, a review. J Nanoparticles 2013:24

6. Yu F, Zhang L, Huang Y, Sun K, David AE, Yang VC (2010) The magnetophoretic mobility and superparamagnetism of core-shell iron oxide nanoparticles with dual targeting and imaging functionality. Biomaterials 31:5842-5848

7. Lu Y, Proch S, Schrinner M, Drechsler M, Kempe R, Ballauff M (2009) Thermosensitive core-shell microgel as a nanoreactor for catalytic active metal nanoparticles. J Mater Chem 19:3955-3961 
8. Chen T, Xu P, Luoetal Y (2009) Preparation of poly(butylacrylate)poly(methyl methacrylate) (core-shell)/phosphor composite particles and its application in PVC matrix. J Appl Polym Sci 114:496-502

9. Buxton GA, Nigel C (2007) Drug diffusion from polymer coreshell nanoparticles. Soft Matter 3:1513-1517

10. Wei S, Wang Q, Zhu J et al (2011) Multifunctional composite core-shell nanoparticles. Nanoscale 3:4474-4502

11. Mahdavian AR, Ashjari M, Mobarakeh HS (2008) Nanocomposite particles with core-shell morphology. Preparation andcharacterization of $\mathrm{Fe}_{3} \mathrm{O}_{4}$-poly(butylacrylate-styrene)particles via miniemulsion polymerization. J Appl Polym Sci 110:1242-1249

12. Lee HY, Rwei SP, Wang L, Chen PH (2008) Preparation and characterization of core-shell polyaniline-polystyrene sulfonate@ $\mathrm{Fe}_{3} \mathrm{O}_{4}$ nanoparticles. Mater Chem Phys 112:805-809

13. Ossoss KM, Hassan MER, Al-Hussaini AS (2019) Novel $\mathrm{Fe}_{2} \mathrm{O}_{3}$ @PANI-o-PDA core-shell nanocomposites for photocatalytic degradation of aromatic dyes. J Polym Res 26:199

14. Mahdavi Z, Rezvani H, Moraveji MK (2020) Core-shell nanoparticles used in drug delivery-microfluidics: a review. RSC Adv 10:18280-18295

15. Li X, Zuo J, Guo Y, Yuan X (2004) Preparation and characterization of narrowly distributed nanogels with temperature-responsive core and pH responsive shell. Macromolecules 37:10042-10046

16. Ballauff M, Lu Y (2007) Smart nanoparticles: Preparation, characterization and applications. Polymer 48:1815-1823

17. Blackburn W, Lyon L (2008) Size-controlled synthesis of monodisperse core/shell nanogels. Colloid Polym Sci 286:563-569

18. Xiao XC, Chu LY, Chen WM, Wang S, Li Y (2003) Positively thermo-sensitive monodisperse core-shell microspheres. Adv Funct Mater 13:847-852

19. Mertz JL, Fard ZH, Malliakas CD, Manos MJ, Kanatzidis MG (2013) Selective removal of $\mathrm{Cs}^{+}, \mathrm{Sr}^{2+}$, and $\mathrm{Ni}^{2+}$ by $\mathrm{K}_{2 \mathrm{x}} \mathrm{Mg}_{\mathrm{x}} \mathrm{Sn}_{3}-\mathrm{S}_{6}$ $(\mathrm{x}=0.5-1)(\mathrm{KMS}-2)$ relevant to nuclear waste remediation. Chem Mater 25:2116-2127

20. Martinez RC, Olguin MT, Rios MS (2010) Cesium sorption by clinoptilolite-rich tuffs in batch and fixed-bed systems. Desalination 258:164-170

21. Sangvanich T, Sukwarotwat V, Wiacek RJ, Grudzien RM, Fryxell GE, Addleman RS, Timchalk C, Yantasee W (2010) Selective capture of cesium and thallium from natural waters and simulated wastes with copper ferrocyanide functionalized mesoporous silica. J Hazard Mat 182:225-231

22. Alamudy HA, Cho K (2018) Selective adsorption of cesium from an aqueous solution by a montmorillonite-prussian blue hybrid. Chem Eng J 349:595-602

23. El-Naggar MR, El-Kamash AM, El-Dessouky MI, Ghonaim AK (2008) Two-step method for preparation of NaA-X zeolite blend from fly ash for removal of cesium ions. J Hazard Mater 154:963-972

24. Wang J, Zhuang S, Liu Y (2018) Metal hexacyanoferrates-based adsorbents for cesium removal. Coord Chem Rev 374:430

25. Zheng YH, Qiao JH, Yuan JH, Shen JF, Aj W, Niu L (2017) Electrochemical removal of radioactive cesium from nuclear waste using the dendritic copper hexacyanoferrate/carbon nanotube hybrids. Electrochim Acta 257:172-180

26. Kaygun AK, Akyil S (2007) Study of the behavior of thorium adsorption on PAN/zeolite composite adsorbent. J Hazard Mater 147:357-362

27. Clarke TD, Wai CM (1998) Selective removal of cesium from acid solutions with immobilized copper ferrocyanide. Anal Chem 70:3708

28. Rao SV, La KB, Narasimhan SV, Ahmed J (1999) Copper ferrocyanidepolyurethane foam as a composite ion exchanger for removal of radioactive cesium. J Radioanal Nucl Chem 240:269
29. Nilchi A, Saberi R, Moradi M, Azizpour H, Zarghami R (2011) Adsorption of cesium on copper hexacyanoferrate-PAN composite ion exchanger from aqueous solution. Chem Eng J 172:572

30. Dwivedi C, Kumar A, Singh KK, Juby AK, Kumar M, Wattal PK, Bajaj PN (2013) Copper hexacyanoferrate-polymer composite beads for cesium ion removal: Synthesis, characterization, sorption, and kinetic studies. J Appl Polym Sci 129:152

31. Chaudhury S, Pandey AK, Goswami A (2015) Copper ferrocyanide loaded track etched membrane: an effective cesium adsorbent. J Radioanal Nucl Chem 304:697

32. Kim YK, Kim T, Kim Y, Harbottle D, Lee JW (2017) Highly effective Cs+ removal by turbidity-free potassium copper hexacyanoferrate- immobilized magnetic hydrogels. J Hazard Mater 340:130

33. Metwally AM, Shaaban AF, Azab MM, Mahmoud AA, Ali HM (2020) Synthesis, characterization, morphology and adsorption performance towards $\mathrm{cu}^{+2}$ ions of nano-sized copolymers of anthranilic acid and o-aminophenol poly(anthranilic acid-co-oaminophenol). J Polym Res 27:90

34. Shaaban AF, Khalil AA, Radwan M, El-Hefnawy M, El-Khawaga HA (2017) Synthesis, characterization and application of a novel nanometer-sized chelating resin for removal of cu(II), co(II) and $\mathrm{Ni}(\mathrm{II})$ ions from aqueous solutions. J Polym Res 62:24-165

35. Nilchia A, Saberia R, Moradib M, Azizpourb H, Zarghamib R (2011) Adsorption of cesium on copper hexacyanoferrate-PAN composite ion exchanger from aqueous solution. Chem Eng J 172:572-580

36. Yang H, Li H, Zhai J, Yu H (2015) In situ growth of Prussian blue nanocrystal within $\mathrm{Fe}^{3+}$ crosslinking PAA resin for radio cesium highly efficient and rapid separation from water. Chem Eng J 277:40-47

37. Haas PA (1993) A review of information on ferrocyanide solids for removal of cesium from solutions. Sep Sci Technol 28:2479-2506

38. Kim JO, Lee SM, Jeon C (2014) Adsorption characteristics of sericite for cesium ions from an aqueous solution. Chem Eng Res Des 92:368-374

39. Khandaker S, Toyohara Y, Kamida S, Kuba T (2018) Adsorptive removal of cesium from aqueous solution using oxidized bamboo charcoal. Water Resour Ind 19:35-46

40. Langmuir I (1918) The adsorption of gases on plane surfaces of glass, mica and platinum. J Am Chem Soc 40:1361-1403

41. Freundlich H (1906) Adsorption in solution. Phys Chem Soc 40:1361-1368

42. Temkin MJ, Phyzev V (1940) Recent modifications to Langmuir isotherms. Acta Physiochim, USSR 12:217-222

43. Metwally E, El-Zakla T, Ayoub RR (2008) Thermodynamics study for the sorption of ${ }^{134} \mathrm{Cs}$ and ${ }^{60} \mathrm{Co}$ radionuclides from aqueous solutions. J Nucl Radiochem Sci 9:1-6

44. Dubinin MM, Radushkevich LV (1947) Equation of the characteristic curve of activated charcoal. Proc Acad Sci Phys Chem Sect USSR 55:331-333

45. El-Bahy SM, El-Bahy ZM (2017) Immobilization of 2-amino pyridine onto poly(acrylonitrile-co- N, Ń-methylenebisacrylamide) nanoparticles for the removal of $\mathrm{Hg}$ (II), $\mathrm{Cd}$ (II) and $\mathrm{Cr}(\mathrm{III})$ : Batch and column techniques. J Environ Chem Eng 5:3560-3571

46. Li X, Wu X, Chen J, Li Y, Yang Y (2019) Alginate-enfolded copper hexacyanoferrate graphene oxide granules for adsorption of low-concentration cesium ions from aquatic environment. J Radioanal Nucl Chem 320:655-663

47. Tao Q, Zhang X, Huang D, Huang G, Fan J, Peng H, Dai Y, Prabaharan K (2019) Copper hexacyanoferrate nanoparticle -decorated biochar produced from pomelo peel for cesium removal from aqueous solution. J Radioanal Nucl Chem $322: 791$ 
48. Kima YK, Baea K, Kima Y, Harbottle D, Leea JW (2018) Immobilization of potassium copper hexacyanoferrate in doubly crosslinked magnetic polymer bead for highly effective $\mathrm{Cs}^{+}$removal and facile recovery. J Huz Mat 340:130

49. Kim Y, Kim YK, Kim S, Harbottle D, Lee JW (2017) Nanostructured potassium copper hexacyanoferrate-cellulose hydrogel for selective and rapid cesium adsorption. Chem Eng J 313:1042-1050

50. Kim Y, Eom HH, Kim D, Harbottle D, Lee JW (2021) Adsorptive removal of cesium by electrospun nanofibers embedded with potassium copper hexacyanoferrate. Sep Purif Technol 255:117745

51. Lagergren S (1898) Zur theorie der sogenannten adsorption gel^ster stoffe, Kungliga Svenska Vetenskapsakademiens. Handlingar 24:1-39

52. Ho YS (2006) Second order kinetic model for the sorption of cadmium on to tree fern: a comparison of linear and nonlinear methods. Water Res 40:119-125
53. Weber WJ, Morris JC (1964) Equilibria and capacities for adsorption on carbon. J Sanitary Eng Div 90:79-91

54. Chien SH, Clayton WR (1980) Application of Elovich equation to the kinetics of phosphate release and sorption on soils. Soil Sci Soc Am J 44:265-268

55. Donia AM, Atia AA, Daher AM, Desouky OA, Elshehy EA (2011) Selective separation of U(VI) from its solutions using amine modified silica gel produced from leached zircon. Int $\mathbf{J}$ Miner Process 101:81-88

56. Abdel-Karim AM, Zaki AA, Elwan W, El-Naggar MR, Gouda MM (2016) Experimental and modeling investigations of cesium and strontium adsorption onto clay of radioactive waste disposal. Appl Clay Sci 132:391-401

Publisher's Note Springer Nature remains neutral with regard to jurisdictional claims in published maps and institutional affiliations. 